\title{
Mineral deposition promoted by resin-based sealants with different calcium phosphate additions
}

\section{Fabio Rocha BOHNS(a) \\ Vicente Castelo Branco LEITUNE(a) \\ Gabriela de Souza BALBINOT(a) \\ Susana Maria Werner SAMUEL ${ }^{(a)}$ \\ Fabricio Mezzomo COLLARES(a) \\ (a) Universidade Federal do Rio Grande do Sul - UFRGS, School of Dentistry, Dental Materials Laboratory, Porto Alegre, RS, Brazil.}

Declaration of Interests: The authors certify that they have no commercial or associative interest that represents a conflict of interest in connection with the manuscript.

Corresponding Author:

Fabricio Mezzomo Collares

E-mail: fabricio.collares@ufrgs.br

htrps://doi.org/10.1590/1807-3107bor-2019.vol33.0101

Submitted: February 20, 2019

Accepted for publication: September 1, 2019

Last revision: October 3, 2019
Abstract: The aim of this study was to evaluate the influence of different calcium phosphates (CaPs) on the physical, biological, and remineralizing properties of experimental resin-based sealants (RBSs). Triethylene-glycol dimethacrylate $(90 \mathrm{wt} \%)$ and bisphenol A-glycidyl methacrylate $(10 \mathrm{wt} \%)$ were used to produce resin-based sealants. Hydroxyapatite $\left(\mathrm{S}_{\mathrm{HAp}}\right), \alpha$-tricalcium phosphate $\left(\mathrm{S} \alpha_{\text {-TCP }}\right)$ and octacalcium phosphate $\left(\mathrm{S}_{\mathrm{OCP}}\right)$ were added to the sealants in a $10 \mathrm{wt} \%$ concentration. One group without CaPs was used as the control group $\left(\mathrm{S}_{\mathrm{CG}}\right)$. The degree of conversion (DC) was assessed with Fourier-transformed infrared spectroscopy, whereas cytotoxicity was tested with the HaCaT keratinocyte cell line. The ultimate tensile strength (UTS) was used to assess the mechanical strength of the experimental RBSs. Sealed enamel was used for colorimetric assay. Mineral deposition was assessed with Raman spectroscopy after 7, 14, and 28 days of sample immersion in artificial saliva. Scanning electron microscopy was used to analyze the surface morphology after 28 days of immersion. The addition of $10 \mathrm{wt} \%$ of fillers significantly reduced the DC of sealants. $\mathrm{S}_{\mathrm{OCP}}$ groups showed reduced cell viability. Higher UTS was found for $S \alpha_{\text {-TCP }}$ and $S_{\text {HAp. }}$. The color analysis showed that $\mathrm{S}_{\mathrm{GC}}$ and demineralized teeth presented higher mismatches with the sound tissue. Mineral deposition was observed for $S_{\text {HAp }}$ and $S \alpha_{\text {-TCP }}$ after 7 days, with increased phosphate content and mineral deposits for $S_{\text {HAp }}$ after 28 days. RBS with the addition of $10 \%$ HAp promoted increased mineralization in vitro after 28 days, and did not affect cell viability, DC, mechanical properties, or RBS color in the enamel.

Keywords: Dental Caries; Calcium Phosphates; Durapatite.

\section{Introduction}

Untreated dental caries remains a major problem in primary and permanent teeth. ${ }^{1}$ Both noninvasive and microinvasive approaches have been applied to prevent caries progression and formation of cavities that may impact tooth aesthetics and function. ${ }^{2,3}$ Microinvasive approaches, such as the sealing of pits and fissures, are effective in areas of the tooth that are more prone to caries development due to anatomic characteristics that make it more difficult to perform cleaning ${ }^{4,5}$ In these high-risk areas, 
the use of sealants is a cost-effective method to prevent caries lesions and their progression..$^{6,7}$

Sealing may be performed with different materials, such as glass ionomer cements or resin-based materials. Resin-based sealants (RBSs) have been used since the 1960s and are designed to penetrate inside deep regions of the tooth anatomy, and bond micromechanically to enamel, thus preventing demineralization in these regions. ${ }^{8,9}$ Even though caries sealants are able to hamper the progression of initial caries lesions, the caries disease must also be controlled ${ }^{10}$ with noninvasive strategies, such as oral hygiene education and healthy dietary practices. The success of these strategies is highly dependent on the patient's cooperation and use of sealants, especially in high-risk patients, in which case they may prevent against new caries lesions in surrounding areas. ${ }^{7}$ The application of RBS alone is unable to stimulate remineralization at the resinenamel interface to provide protection against further acid challenges. ${ }^{11}$

Calcium phosphates (CaPs) are inorganic compounds with structures and compositions similar to those of hard tissues of the human body. ${ }^{12}$ These similarities have prompted studies on their use in regenerative medicine, as potential bioactive materials for application in various medical and dental treatments. ${ }^{13}$ Although the ability of CaPs to promote mineral deposition depends on an increase in the calcium and phosphate contents of the medium, this mechanism is different for each CaP structure. ${ }^{14}$ Hydroxyapatite (HAp) is the main mineral in the inorganic phase of the tooth and bone. Octacalcium phosphate (OCP) is known as a precursor of apatite, and has been studied as a rich calcium and phosphate source of mineralization, owing to its high solubility. ${ }^{15}$ Among the tricalcium phosphates, alpha-tricalcium phosphate $(\alpha-T C P)$ is used in bone cements due to its ability to form calcium-deficient HAp when dissolved in an aqueous medium. HAp, $\alpha-\mathrm{TCP}$, and OCP have already been studied in different applications in dentistry, ${ }_{1}^{16-18}$ and the addition of CaPs to RBS may be an alternative to promote the remineralization of surrounding tissues and prevent further demineralization. ${ }^{11}$ The aim of this study was to evaluate the influence of different CaPs on the physical, biological, and remineralizing properties of experimental resinbased sealants.

\section{Methodology}

\section{Experimental enamel resin sealant preparation}

The experimental sealants were prepared by mixing $90 \mathrm{wt} \%$ of triethylene-glycol dimethacrylate (TEGDMA), $10 \mathrm{wt} \%$ of bisphenol A-glycidyl methacrylate (BisGMA), $1 \mathrm{~mol} \%$ of camphorquinone (CQ), and $1 \mathrm{~mol} \%$ of ethyl 4-dimethylaminebenzoate (EDAB), all obtained from Sigma-Aldrich (St. Louis, USA). CaPs were added to $10 \mathrm{wt} \%$ and separated into three experimental groups, namely HAp $\left(S_{\mathrm{HAp}}\right), \alpha-\mathrm{TCP}$ $\left(\mathrm{S} \alpha_{-\mathrm{TCP}}\right)$, and OCP $\left(\mathrm{S}_{\mathrm{OCP}}\right)$. One group without filler was used as the control group $\left(\mathrm{S}_{\mathrm{CG}}\right)$. The characteristics of the $\mathrm{CaP}$ particles are described in Table 1. These particles were mixed with a polymeric blend, in an ultrasonic bath (L100; Schuster, Santa Maria, RS, Brazil), for eight minutes to ensure complete homogeneity of the sealants.

\section{Degree of conversion}

The degree of conversion (DC) of the experimental sealants was assessed with a Fourier-transformed infrared spectrophotometer (FT-IR Vertex 70; Bruker Optics, Ettlingen, Germany), equipped with an attenuated total reflectance crystal (Platinum

Table 1. Characterization of tested calcium phosphates

\begin{tabular}{lccccc}
\hline Group & Chemical formula & $\mathrm{Ca} / \mathrm{p}$ molar ratio & Particle size & Crystalline structure & Solubility at $25^{\circ} \mathrm{C}, \mathrm{g} / \mathrm{l}$ \\
\hline $\mathrm{HAp}$ & $\mathrm{Ca}_{10}\left(\mathrm{PO}_{4}\right)_{6}(\mathrm{OH})_{2}$ & 1.67 & $26.8 \mathrm{~nm}$ & Hexagonal & $0.0003^{38}$ \\
$\alpha$-TCP & $\alpha-\mathrm{Ca}_{3}\left(\mathrm{PO}_{4}\right)_{2}$ & 1.50 & $6.03 \mu \mathrm{m}$ & Monoclinic & $0.0022^{12}$ \\
OCP & $\mathrm{Ca}_{8}\left(\mathrm{HPO}_{4}\right)_{2}\left(\mathrm{PO}_{4}\right)_{4} \cdot{ }_{5} \mathrm{H}_{2} \mathrm{O}$ & 1.33 & $4.94 \mu \mathrm{m}$ & Triclinic & $0.0081^{12}$ \\
\hline
\end{tabular}


ATR-QL; Bruker Optics, Ettlingen, Germany). The sealants were dispensed directly onto the diamond crystal $(n=3)$, in sections measuring $4 \mathrm{~mm}$ diameter and $2 \mathrm{~mm}$ thick. The spectra were taken before and after photocuring for 20 seconds, with 1,200 mW/ $\mathrm{cm}^{2}$ power (Radii Cal; SDI, Bristol, PA, USA). DC was calculated using the intensities of the aliphatic $\mathrm{C}=\mathrm{C}$ peak at $1,637 \mathrm{~cm}^{-1}$, compared with an internal standard carbonyl group $\mathrm{C}=\mathrm{O}$ peak at $1,715 \mathrm{~cm}^{-1}$ before and after light-curing. ${ }^{19}$

\section{Cytotoxicity}

\section{Cell culture}

The immortalized human keratinocyte HaCaT cell line was used (Banco de Células do Rio de Janeiro, Rio de Janeiro, Brazil) in this study. The cells were immersed in Dulbecco's modified Eagle medium (DMEM), complemented with $100 \mathrm{U} / \mathrm{mL}$ of penicillin, $100 \mu \mathrm{g} / \mathrm{mL}$ of streptomycin, $10 \%$ of fetal bovine serum, and $2 \mathrm{mM}$ of L-glutamine. The cells were cultured at $37^{\circ} \mathrm{C}$, under $5 \% \mathrm{CO}_{2} / 95 \%$ air atmosphere, and the medium was changed every two to three days.

\section{SRB cytołoxicity assay}

Eluates were prepared prior to cell treatment. Sealant specimens $(4 \mathrm{~mm}$ in diameter and $1 \mathrm{~mm}$ in height; $\mathrm{n}=3$ ) were sterilized in an autoclave, and each was immersed in $1 \mathrm{~mL}$ of DMEM for 24 hours at $37^{\circ} \mathrm{C}$. The cells $\left(5 \times 10^{3}\right)$ were seeded in 96-well plates; after 24 hours, each well was treated with $100 \mu \mathrm{L}$ of eluates added to the seeded wells. After 72 hours in culture, the cells were fixed in $50 \mu \mathrm{L}$ of $50 \%$ trichloroacetic acid (Sigma-Aldrich, St. Louis, USA). Each well was covered with $50 \mu \mathrm{L}$ of $0.4 \%$ sulforhodamine B (SRB) (Sigma-Aldrich, St. Louis, USA), as described previously. ${ }^{20}$ The quantification of viable cells was performed for absorbance at $560 \mathrm{~nm}$ in a microplate spectrophotometer (Multiskan GO, Thermo Fisher Scientific, Waltham, USA), following the suspension of cells in 10\% Trizma (Sigma-Aldrich, St. Louis, USA). Untreated medium was used as a control to normalize the percentage of viable cells.

\section{Ultimate tensile strength}

The ultimate tensile strength (UTS) analysis was performed with hourglass-shaped samples $(n=5)$ $8 \mathrm{~mm}$ long, $2 \mathrm{~mm}$ wide, and $1 \mathrm{~mm}$ thick, with a cross-sectional area of $1 \mathrm{~mm}^{2}$ produced in a metallic matrix with a polyester strip at the bottom and top of the matrix. The samples were light-activated, applied for 20 seconds on each side, and stored in water for 24 hours at $37^{\circ} \mathrm{C}$ prior to testing. The UTS test was performed in a mechanical testing machine (Shimadzu EZ-SX; Shimadzu Corp., Kyoto, Japan) with a crosshead speed of $1 \mathrm{~mm} / \mathrm{min}$.

\section{Mineral deposition}

Mineral deposition was performed using micro-Raman spectroscopy (Senterra; Bruker Inc., Karlsruhe, Germany) equipped with a $100-\mathrm{mW}$ diode laser adjusted to a 785-nm wavelength with a spectral resolution of $\approx 3.5 \mathrm{~cm}^{-1}$ in three coadditions for five seconds. Specimens $4 \mathrm{~mm}$ in diameter and $2 \mathrm{~mm}$ high were produced for this analysis. Baseline measurements were taken after 24-hour immersion in distilled water. Then, one disc from each group was immersed in artificial saliva, prepared as described by Karlinsey et al. ${ }^{24}$ Specimens were analyzed at 7, 14, and 28 days after immersion. The phosphate peak of $960 \mathrm{~cm}^{-1}$ was used to measure the intensity of mineral deposits on the samples. After 28 days, the surface of the samples was scanned using scanning electron microscopy (SEM) (JSM 6060; JEOL Ltd., Tokyo, Japan), with the device set to a voltage of $3 \mathrm{kV}$.

\section{Colorimetric assay}

Thirty extracted bovine permanent incisors were stored in distilled water for 7 days after extraction. The samples were prepared by grounding flat the labial surface of the crowns, using silicon carbide sandpaper with grits of 600, 1,200 and 2,000 (Klingspor, Haiger, Germany), under water cooling. Then, the flat surfaces were polished (1- $\mu \mathrm{m}$ alumina suspension; Fortel, São Paulo, Brazil) in a polishing machine (Model $3 v$; Arotec, Cotia, Brazil) under water cooling for 60 seconds. Prior to demineralization, each enamel surface was partially covered with acid-resistant nail varnish, leaving an open window $5 \mathrm{~mm} \times 5 \mathrm{~mm}$. 
Demineralization was created by subjecting the samples to an acid solution ( $\mathrm{pH}$ : 4.4) produced as described previously. ${ }^{21}$ The solution was maintained at $37^{\circ} \mathrm{C}$ for 72 hours, and the $\mathrm{pH}$ was measured twice a day using a pH meter (DM-22; Digimed, São Paulo, Brazil). Six teeth were used for each group to complete the colorimetric analysis. Six teeth were left with no demineralization, in order to conduct the analysis for sound enamel, and six remained unsealed to perform the demineralized enamel analysis. The demineralized enamel surfaces were etched with 37\% phosphoric acid (Dentsply, York, USA) for 30 seconds, and rinsed with distilled water for the same amount of time. After air-drying, the experimental sealants were gently applied to the enamel surfaces with a microbrush (KG Sorensen; Cotia, Brazil) for 20 seconds, and light-cured for 20 seconds (Radii Cal; SDI, Bristol, USA). Color measurements were performed using a reflectance spectrophotometer (CARY 5000 UV-Vis-NIR; Agilent Technologies, Santa Clara, USA) equipped with a DRA-1800 integrating sphere. The color of each sample was measured and quantified in terms of three coordinate values $\left(\mathrm{L}^{*}, \mathrm{a}^{*}\right.$, and $\left.\mathrm{b}^{*}\right)$, as established by the Commission Internationale de L'Eclairage (CIE). The color of the sound demineralized and sealed enamel samples was assessed under standardized conditions according to the CIE L*a* $\mathrm{b}^{*}$ system. The differences among the parameters were used to calculate the $\Delta \mathrm{E}$, such as overall change in color, measured by comparing the mean $\Delta \mathrm{E}$ of sound teeth with the $\Delta \mathrm{E}$ of demineralized and sealed teeth.

\section{Statistical analysis}

Descriptive analysis of the specimens was performed for micro-Raman and SEM image analyses. The statistical analysis was performed using SigmaPlot 12.0 (Systat Software, San Jose, USA). The normality of data was evaluated using the Shapiro-Wilk test. The degree of conversion, the cytotoxicity, the UTS, and the colorimetric results were analyzed using one-way analysis of variance and Tukey's test.

\section{Results}

The DC values of RBSs (Table 2) ranged from $57.16 \%$ to $50.71 \%$, with statistically significant higher values for $\mathrm{S}_{\mathrm{GC}}$, compared with $\mathrm{CaP}$-containing sealants ( $p<0.05$; power: $81 \%$ ). The percentages of cell viability are represented separately in Table 2. The $\mathrm{S}_{\mathrm{OCP}}$ group presented statistically significant lower cell viability (82.82\%; $p<0.001$; power: $100 \%)$ than the $\mathrm{S}_{\mathrm{CG}}, \mathrm{S}_{\mathrm{HAp}}$ and $\mathrm{S} \alpha_{\text {-TCP }}$ groups $(97.12 \%, 95.88 \%$, and $94.26 \%$, respectively). UTS results are shown in Table 2. $S \alpha_{\text {-тср }}$ presented statistically significant higher UTS values than $S_{\mathrm{CG}}$ and $S_{\mathrm{OCP}}(\mathrm{p}<0.01$; power: $97 \%$ ). Mineral deposition was found on the surface of samples containing $\alpha$-TCP and HAp after 7 days of immersion in artificial saliva (Figures 1 and 2). A greater intensity in the phosphate peak $\left(960 \mathrm{~cm}^{-1}\right)$ was observed in $\mathrm{S}_{\mathrm{HAp}}$ after 28 days (Figure 2). SEM images showed that apatite-like particles were deposited on the surface of samples after 28 days of immersion (Figure 2). Colorimetric measurements are shown in Table 3. Higher $\Delta \mathrm{E}$ values were found for demineralized teeth, compared with $\mathrm{S}_{\mathrm{OCP}}, \mathrm{S}_{\mathrm{TCP}}$ $S_{\text {HAp }}$ values ( $p<0.05$; power: $\left.84.4 \%\right)$. $S_{\text {GC }}$ presented values similar to those of demineralized and sealed teeth. Finally, L* values were statistically higher for demineralized teeth than sound sealed surfaces ( $p<0.05$; power: $99 \%$ ).

Table 2. Degree of conversion (\%), cell viability (\%) and ultimate tensile strength means and standard deviations.

\begin{tabular}{lccc}
\hline Group & Degree of conversion (\%) & cell viability (\%) & Ultimate tensile strength (MPa) \\
\hline$S_{C G}$ & $57.16 \pm 1.85^{\mathrm{A}}$ & $97.12 \pm 3.35^{\mathrm{A}}$ & $22.64 \pm 6.88^{\mathrm{C}}$ \\
$S_{\mathrm{OCP}}$ & $50.71 \pm 1.57^{\mathrm{B}}$ & $82.82 \pm 1.95^{\mathrm{B}}$ & $23.78 \pm 5.97^{\mathrm{BC}}$ \\
$S_{\alpha-T C P}$ & $51.84 \pm 1.70^{\mathrm{B}}$ & $94.24 \pm 1.62^{\mathrm{A}}$ & $35.44 \pm 6.72^{\mathrm{A}}$ \\
$S_{\text {HAP }}$ & $52.61 \pm 1.51^{\mathrm{B}}$ & $95.87 \pm 0.50^{\mathrm{A}}$ & $30.99 \pm 5.40^{\mathrm{AB}}$ \\
\hline
\end{tabular}

Different uppercase letters indicate statistical difference among groups. 


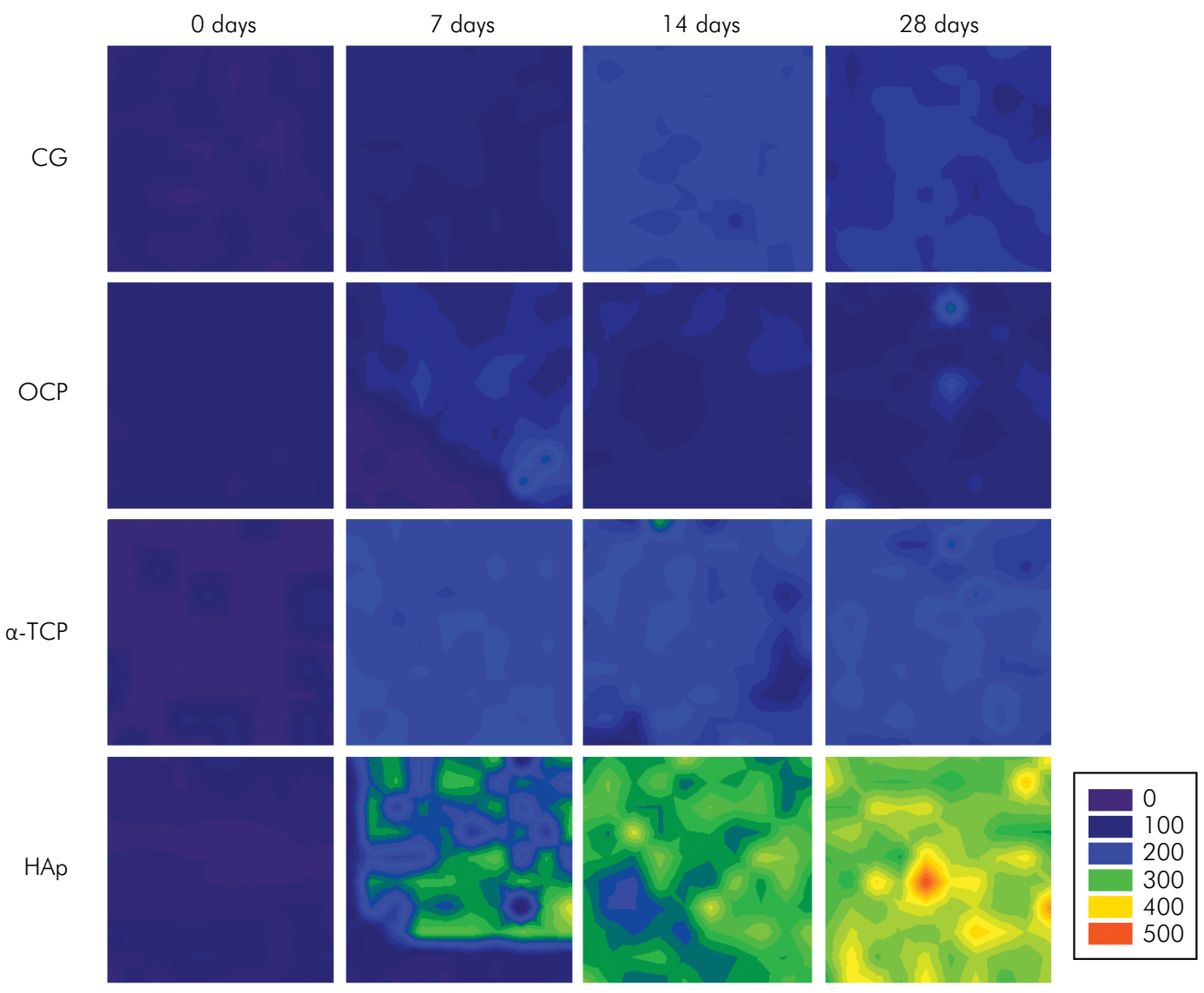

Figure 1. Color representation of the intensity of phosphate peaks $\left(960 \mathrm{~cm}^{-1}\right)$ in the different tested groups after 7,14 and 28 days of immersion in saliva. Higher intensities are represented by red/green. Blue regions represent lower or total absence of phosphate intensity.

Different lowercase letter indicates a statistical difference in the same row $(\mathrm{p}<0.05)$; Different uppercase letter indicates a statistical difference in the same column $(\mathrm{p}<0.05)$.

\section{Discussion}

CaPs have been widely studied due to their potential to induce mineral deposition..$^{13}$ In this study, three different calcium phosphates (HAp, OCP, and $\alpha$-TCP) were added to a resin-based sealant. The DC was influenced by the addition of HAp and $\alpha$-TCP, whereas lower cell viability was found for OCP. Mineral deposition was observed for the $\alpha$-TCP and HAp samples after 7 days of immersion in saliva. After 28 days, Raman analysis and SEM images confirmed a higher rate of mineral deposition in the $S_{\mathrm{HAp}}$ group.
The addition of fillers to a polymeric blend may lead to a different light-scattering pattern in the composite, resulting in differences in the number of converted monomers in the composite. ${ }^{22,23} \mathrm{All} \mathrm{CaP-containing}$ groups presented lower DC values than the control group (Table 2). The addition of filler resulted in increased opacity of the experimental sealants, and this could promote a reduction in light passage during polymerization. ${ }^{24}$ Although a statistically significant difference was found, the values obtained were similar to those for commercial sealants. ${ }^{25}$ Differences in DC may lead to reduced mechanical properties and increased cytotoxicity. ${ }^{26}$ Conversely, in the UTS analysis, the RBSs with HAp and $\alpha$-TCP additions presented higher tensile strengths than the sealants without filler $\left(\mathrm{S}_{\mathrm{GC}}\right.$; Table 2$)$. Sealants must have adequate mechanical properties, since they are frequently placed in areas subjected to masticatory 
forces, such as occlusal areas. The addition of fillers to resin-based materials may increase their tensile strength, ${ }^{27}$ and this phenomenon could have occurred with the addition of HAp and $\alpha-\mathrm{TCP}$, considering that their crystalline structure may be responsible

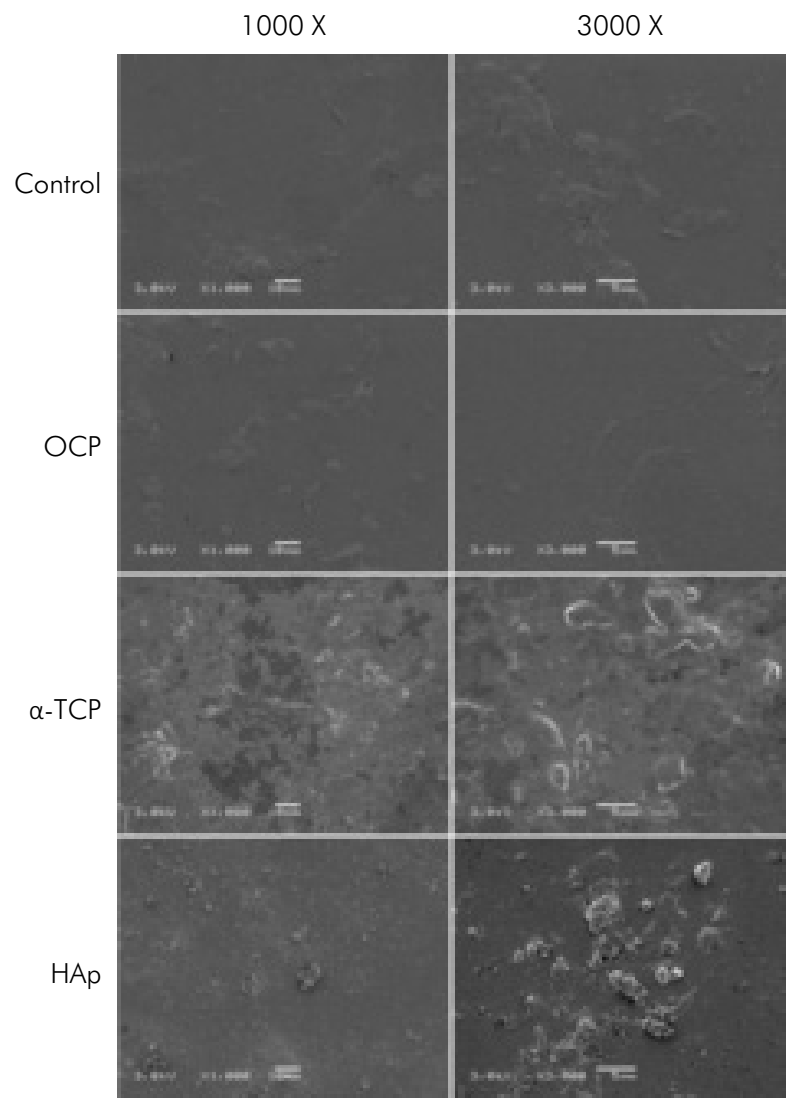

Figure 2. SEM images $(1,000 \times$ and $3,000 \times)$ of samples after immersion in saliva for 28 days. Mineral deposits are observed for the HAp and $\alpha$-TCP groups and are better observed at $3,000 \times$ magnification. OCP did not promote deposition in the specimens. for higher mechanical strength, in comparison with the less packed structure of $\mathrm{OCP}$, as shown in Table 1.

The experimental sealants were produced with high TEGDMA content, a formulation chosen to adjust the viscosity of the RBSs and facilitate penetration of materials in the pits and fissures. However, TEGDMA is known to be the most leachable monomer among the dental composites, and its release may cause cell death. ${ }^{26}$ The release of unreacted monomers may affect gingival tissues, and human keratinocytes were used in this study as an epithelial cell line to assess the influence of materials on cell behavior. Higher viability was observed for RBSs containing HAp and $\alpha$-TCP , but there was no statistically significant difference compared with the control group (Table 2). Since OCP is the most soluble ${ }^{13}$ filler, and its release may influence polymeric matrix stability, other unreacted monomers may be leached from the TEGDMA/BisGMA blend. Higher hydrolytic stability of the fillers in $\mathrm{S}_{\text {HAp }}$ and $S \alpha_{\text {-тст }}$ probably leads to higher cell viability.

The addition of bioactive fillers may affect the color of RBSs, and be inadequate if placed in aesthetic areas. In the present study, demineralized enamel was sealed with different $\mathrm{CaP}$-containing sealants, the colors of which were analyzed with the CIE L*a*b* system. The application of different colorimetric measurements, such as the CIE L*a*b* and the CIED2000, results in variations in visual perception and tooth aesthetics. ${ }^{33}$ Although CIED2000 is regarded as representing better visual perception in dentistry, ${ }^{34}$ the CIE L*a* $b^{*}$ parameters may be effective in detecting differences between demineralized and sound enamel before and after sealing procedures. Higher values of $\Delta \mathrm{E}$ were observed for $S_{\mathrm{GC}}$ and demineralized surfaces,

Table 3. Colorimetric analysis of sound, demineralized and sealed enamel. L*a*b parameters and $\Delta E$ calculated for sealants in sound and demineralized enamel.

\begin{tabular}{|c|c|c|c|c|c|}
\hline Group & Sound $(\Delta \mathrm{E})$ & Demineralized $(\Delta \mathrm{E})$ & $L^{*}$ & $a^{*}$ & $b^{*}$ \\
\hline Sound & - & - & $88.65 \pm 0.97^{a}$ & $-0.43 \pm 0.09^{a}$ & $-0.51 \pm 0.95^{a}$ \\
\hline Demineralized & - & - & $93.22 \pm 1.61^{b}$ & $-0.76 \pm 0.12^{a}$ & $-2.13 \pm 0.39 b$ \\
\hline $\mathrm{s}_{\mathrm{CG}}$ & $1.32 \pm 0.91 \mathrm{Aa}$ & $4.14 \pm 1.91 \mathrm{Ab}$ & $89.31 \pm 0.62^{\circ}$ & $-0.12 \pm 0.14^{a}$ & $-0.66 \pm 0.41^{a}$ \\
\hline SOCP & $1.22 \pm 0.71 \mathrm{Aa}$ & $4.77 \pm 1.63^{\mathrm{Ab}}$ & $88.43 \pm 0.66^{a}$ & $-0.26 \pm 0.12^{a}$ & $-0.66 \pm 0.76^{a}$ \\
\hline$S_{\alpha-T C P}$ & $1.51 \pm 0.40 \mathrm{Aa}$ & $5.03 \pm 1.20^{\mathrm{Ab}}$ & $88.64 \pm 0.55^{a}$ & $-0.08 \pm 0.15^{a}$ & $-0.22 \pm 0.57 a$ \\
\hline$S_{\text {HAp }}$ & $1.60 \pm 0.27^{\mathrm{Aa}}$ & $4.80 \pm 1.39 \mathrm{Ab}$ & $88.75 \pm 0.43^{\circ}$ & $-0.06 \pm 0.13^{a}$ & $-0.02 \pm 0.37^{a}$ \\
\hline
\end{tabular}


indicating that $\mathrm{CaP}$-containing groups attained a color value closer to that of sound tissue (Table 3). In addition to the overall color difference $(\Delta \mathrm{E})$, the lightness-assessed as the $L^{*}$ value-is an important parameter to be considered, since an increase in the $\mathrm{L}^{*}$ parameter may indicate higher demineralization in early caries lesions. ${ }^{35}$ The light-scattering that occurs through poorly mineralized enamel increases $L^{*}$ values closer to 100, which represents the white color balance. Application of sealants to demineralized enamel leads to reduced $L^{*}$ and lightness values for sound enamel, thus indicating that light-scattering in demineralized enamel was improved by the sealing procedure.

Remineralization in already sealed areas may help avoid the formation of new caries lesions, especially in high-risk patients. ${ }^{7}$ The addition of HAp and $\alpha$-TCP to resin sealants promoted in vitro mineral deposition, especially in $\mathrm{S}_{\mathrm{HAp}}$ after 28 days of immersion in artificial saliva. The $\mathrm{CaP}$ mechanism to promote mineral deposition has been studied extensively to date ${ }^{29,36}$, and depends on increasingly higher concentrations of $\mathrm{Ca}^{2+}$ and $\mathrm{PO}_{4}{ }^{3-}$-in the medium. The availability of these ions promotes greater apatite nucleation and mineralization of hard tissues..$^{13}$ Differences in mineral deposition can be explained by variations in $\mathrm{CaP}$ structures (Table 1). OCP has the highest solubility among the tested $\mathrm{CaPs}$, owing to its low crystal arrangement and $\mathrm{Ca} / \mathrm{PO}_{4}$ ratio. Although the triclinic structure of OCP is similar to the hexagonal HAp structure, the presence of a hydrated sublayer in the less densely packed calcium and phosphate atoms ${ }^{30}$ is responsible for the high solubility of OCP. It could be expected that the high solubility of OCP would increase $\mathrm{Ca}^{2+}$ and $\mathrm{PO}_{4}{ }^{3-}$ availability; however, quick loss of these ions prevents the nucleation of apatite crystals, thus explaining the lower mineral formation observed in the present study. The dissolution process may be why the phosphate content was not as high for $\mathrm{S} \alpha_{\text {-TCP }}$ as $S_{\text {HAp. }} \alpha-\mathrm{TCP}$ has a lower $\mathrm{Ca} / \mathrm{P}$ ratio compared with HAp, leading to a reduced level of stability. ${ }^{32}$ The $\alpha-T C P$ used in the present study had the same composition as $\beta-\mathrm{TCP}$, the most frequently used tricalcium phosphate; however, they differ in their crystal structure, which makes $\alpha$-TCP more soluble than $\beta$-TCP. In the present study, monoclinic $\alpha$-TCP was used due to its ability to create calcium-deficient HAp upon hydrolyzation, ${ }^{12}$ thus promoting a nucleation site for mineral deposition. Even though other authors have reported the CaP mechanism, ${ }^{12}$ the mineral deposition of $S \alpha_{\text {-TCP }}$ was lower when compared to that of $S_{\text {HAp. }}$

In vivo remineralization is a complex process, and mineral deposition in vitro is one way to assess the ability of a material to induce phosphate formation on the surface of test samples. In this study, the $S_{\text {HAp }}$ group showed increased phosphate content $\left(960 \mathrm{~cm}^{-1}\right.$ peak; Figure 1) and mineral deposition after 28 days (Figure 2), compared with the other experimental groups. Although it is not possible to extrapolate these in vitro results directly, some studies have suggested that HAp may induce apatite nucleation in tooth and bone. ${ }^{37,38}$ HAp is known as the least soluble CaP, and the stability of the particles is responsible for controlled $\mathrm{Ca}^{2+}$ and $\mathrm{PO}_{4}{ }^{3-}$ release, and later nucleation of mineral deposits. ${ }^{22}$ Nano-sized HAp was used in the present study, whereas OCP and $\alpha-\mathrm{TCP}$ were of micrometric size (Table 1). The different particle sizes used represent a limitation of the present study, since fillers were added by $w t \%$; therefore, $S_{\text {HAp }}$ received a higher volume of particles. Nano-sized HAp has already been synthesized using different methods, ${ }^{39,40}$ whereas little information can be found on the subject of nanometric OCP and $\alpha$-TCP. ${ }^{41}$ The nanometric size of HAp increased the surface area of the particle, thereby increasing the area for calcium phosphate nucleation on the surface of the samples, according to the outcome observed by mineral deposition analysis.

The addition of HAp to enamel resin sealants promoted an increase in the mineral deposition after 28 days of immersion in saliva, and enhanced the potential therapeutic effect of these materials. No cytotoxic effect and adequate mechanical properties were found for $\mathrm{S}_{\text {HAp }}$. The more soluble $\alpha$-TCP and OCP fillers showed little or no mineral deposition, and may not be suitable for the remineralization of pits and fissures and surrounding enamel.

\section{Conclusion}

Resin-based sealants with the addition of $10 \%$ HAp promoted increased mineralization in vitro after 28 days, and did not impact cell viability, mechanical properties, or RBS color in the enamel. 
Mineral deposition promoted by resin-based sealants with different calcium phosphate additions

\section{References}

1. Kassebaum NJ, Bernabé E, Dahiya M, Bhandari B, Murray CJ, Marcenes W. Global burden of untreated caries: a systematic review and metaregression. J Dent Res. 2015 May;94(5):650-8. https://doi.org/10.1177/0022034515573272

2. Filstrup SL, Briskie D, Fonseca M, Lawrence L, Wandera A, Inglehart MR. Early childhood caries and quality of life: child and parent perspectives. Pediatr Dent. 2003 Sep-Oct;25(5):431-40.

3. Casamassimo PS, Thikkurissy S, Edelstein BL, Maiorini E. Beyond the dmft: the human and economic cost of early childhood caries. J Am Dent Assoc. 2009 Jun;140(6):650-7. https://doi.org/10.14219/jada.archive.2009.0250

4. Chestnutt IG, Playle R, Hutchings S, Morgan-Trimmer S, Fitzsimmons D, Aawar N, et al. Fissure seal or fluoride varnish? A randomized trial of relative effectiveness. J Dent Res. 2017 Jul;96(7):754-61. https://doi.org/10.1177/0022034517702094

5. Schwendicke F, Stolpe M, Meyer-Lueckel H, Paris S. Detecting and treating occlusal caries lesions: a cost-effectiveness analysis. J Dent Res. 2015 Feb;94(2):272-80. https://doi.org/10.1177/0022034514561260

6. Akinlotan M, Chen B, Fontanilla TM, Chen A, Fan VY. Economic evaluation of dental sealants: a systematic literature review. Community Dent Oral Epidemiol. 2018 Feb;46(1):38-46. https://doi.org/10.1111/cdoe.12326

7. Al-Jobair A, Al-Hammad N, Alsadhan S, Salama F. Retention and caries-preventive effect of glass ionomer and resin-based sealants: an 18-month-randomized clinical trial. Dent Mater J. 2017 Sep;36(5):654-61. https://doi.org/10.4012/dmj.2016-225

8. Ahovuo-Saloranta A, Forss H, Walsh T, Nordblad A, Mäkelä M, Worthington HV. Pit and fissure sealants for preventing dental decay in permanent teeth. Cochrane Database Syst Rev. 2017 Jul;7:CD001830 https://doi.org/10.1002/14651858.CD001830.pub5

9. Schwendicke F, Jäger AM, Paris S, Hsu LY, Tu YK. Treating pit-and-fissure caries: a systematic review and network meta-analysis. J Dent Res. 2015 Apr;94(4):522-33. https://doi.org/10.1177/0022034515571184

10. Schwendicke F, Frencken JE, Biørndal L, Maltz M, Manton DJ, Ricketts D, et al. Managing carious lesions: consensus recommendations on carious tissue removal. Adv Dent Res. 2016 May;28(2):58-67. https://doi.org/10.1177/0022034516639271

11. Featherstone JD, Fontana M, Wolff M. Novel Anticaries and remineralization agents: future research needs. J Dent Res. 2018 Feb;97(2):125-7. https://doi.org/10.1177/0022034517746371

12. Dorozhkin SV. Calcium orthophosphates (CaPO4): occurrence and properties. Morphologie. 2017 Sep;101(334):125-42. https://doi.org/10.1016/i.morpho.2017.03.007

13. Dorozhkin SV. Calcium orthophosphates in dentistry. J Mater Sci Mater Med. 2013 Jun;24(6):1335-63. https://doi.org/10.1007/s10856-013-4898-1

14. Li Y, Jiang T, Zheng L, Zhao J. Osteogenic differentiation of mesenchymal stem cells (MSCs) induced by three calcium phosphate ceramic (CaP) powders: A comparative study. Mater Sci Eng C. 2017 Nov;80 Supplement C:296-300. https://doi.org/10.1016/i.msec.2017.05.145

15. Shiraishi N, Anada T, Honda Y, Masuda T, Sasaki K, Suzuki O. Preparation and characterization of porous alginate scaffolds containing various amounts of octacalcium phosphate (OCP) crystals. J Mater Sci Mater Med. 2010 Mar;21 (3):907-14. https://doi.org/10.1007/s10856-009-3911-1

16. Garcia IM, Leitune VC, Samuel SM, Collares FM. Influence of different calcium phosphates on an experimental adhesive resin. J Adhes Dent. 2017;19(5):379-84. https://doi.org/10.3290/i.jad.a38997

17. Collares FM, Leitune VC, Portella FF, Santos PD, Balbinot GS, Santos LA, et al. Methacrylate-based root canal sealer containing chlorexidine and $\alpha$-tricalcium phosphate. J Biomed Mater Res B Appl Biomater. 2018 May:106(4):1439-43. https://doi.org/10.1002/ibm.b.33946

18. Balbinot GS, Garcia IM, Samuel SM, Collares FM, Leitune VC. Influence of Octacalcium Phosphate addition on physical-mechanical properties of Glass lonomer Cement. Rev Odonto Ciênc. 2018 Mar;32(3):127-30. https://doi.org/10.15448/1980-6523.2017.3.28062.

19. Collares FM, Portella FF, Leitune VC, Samuel SM. Discrepancies in degree of conversion measurements by FTIR. Braz Oral Res. 22013 Nov-Dec;27(6):453-4. https://doi.org/10.1590/S1806-83242013000600002

20. Orellana EA, Kasinski AL. Sulforhodamine B (SRB) Assay in Cell Culture to Investigate Cell Proliferation. Bio Protoc. 2016 Nov;6(21):e1984. https://doi.org/10.21769/BioProtoc.1984 PMID:28573164

21. ten Cate JM, Duijsters PP. Alternating demineralization and remineralization of artificial enamel lesions. Caries Res. 1982;16(3):201-10. https://doi.org/10.1159/000260599

22. Andrade Neto DM, Carvalho EV, Rodrigues EA, Feitosa VP, Sauro S, Mele G, et al. Novel hydroxyapatite nanorods improve anti-caries efficacy of enamel infiltrants. Dent Mater. 2016 Jun;32(6):784-93. https://doi.org/10.1016/i.dental.2016.03.026

23. Leitune VC, Takimi A, Collares FM, Santos PD, Provenzi C, Bergmann CP, et al. Niobium pentoxide as a new filler for methacrylate-based root canal sealers. Int Endod J. 2013 Mar;46(3):205-10. https://doi.org/10.1111/i.1365-2591.2012.02107.x

24. Habib E, Wang R, Zhu XX. Correlation of resin viscosity and monomer conversion to filler particle size in dental composites. Dent Mater. 2018 Oct;34(10):1501-8. https://doi.org/10.1016/j.dental.2018.06.008 
25. Lucey SM, Santini A, Roebuck EM. Degree of conversion of resin-based materials cured with dual-peak or single-peak LED light-curing units. Int J Paediatr Dent. 2015 Mar;25(2):93-102. https://doi.org/10.1111/ipd.12104

26. Michelsen VB, Moe G, Strøm MB, Jensen E, Lygre H. Quantitative analysis of TEGDMA and HEMA eluted into saliva from two dental composites by use of GC/MS and tailor-made internal standards. Dent Mater. 2008 Jun;24(6):724-31. https://doi.org/10.1016/i.dental.2007.08.002

27. Randolph LD, Palin WM, Leloup G, Leprince JG. Filler characteristics of modern dental resin composites and their influence on physicomechanical properties. Dent Mater. 2016 Dec;32(12):1586-99. https://doi.org/10.1016/i.dental.2016.09.034

28. Yang SY, Piao YZ, Kim SM, Lee YK, Kim KN, Kim KM. Acid neutralizing, mechanical and physical properties of pit and fissure sealants containing melt-derived 45S5 bioactive glass. Dent Mater. 2013 Dec;29(12):1228-35. https://doi.org/10.1016/i.dental.2013.09.007

29. Dorozhkin SV. Bioceramics of calcium orthophosphates. Biomaterials. 2010 Mar;31(7):1465-85. https://doi.org/10.1016/i.biomaterials.2009.11.050

30. Wang L, Nancollas GH. Calcium orthophosphates: crystallization and dissolution. Chem Rev. 2008 Nov;108(11):4628-69. https://doi.org/10.1021/cr0782574

31. Collares FM, Leitune VC, Rostirolla FV, Trommer RM, Bergmann CP, Samuel SM. Nanostructured hydroxyapatite as filler for methacrylate-based root canal sealers. Int Endod J. 2012 Jan;45(1):63-7. https://doi.org/10.1111/j.1365-2591.2011.01948.x

32. Wang X, Huyang G, Palagummi SV, Liu X, Skrtic D, Beauchamp C, et al. High performance dental resin composites with hydrolytically stable monomers. Dent Mater. 2018 Feb;34(2):228-37. https://doi.org/10.1016/i.dental.2017.10.007

33. Gómez-Polo C, Portillo Muñoz M, Lorenzo Luengo MC, Vicente P, Galindo P, Martín Casado AM. Comparison of the CIELab and CIEDE2000 color difference formulas. J Prosthet Dent. 2016 Jan;115(1):65-70. https://doi.org/10.1016/i.prosdent.2015.07.001

34. Pecho OE, Ghinea R, Alessandretti R, Pérez MM, Della Bona A. Visual and instrumental shade matching using CIELAB and CIEDE2000 color difference formulas. Dent Mater. 2016 Jan;32(1):82-92. https://doi.org/10.1016/i.dental.2015.10.015

35. Torres CRG, Borges AB, Torres LM, Gomes IS, Oliveira RS. Effect of caries infiltration technique and fluoride therapy on the colour masking of white spot lesions. J Dent. 2011 Mar;39(3):202-7. https://doi.org/10.1016/i.jdent.2010.12.004

36. Denry I, Kuhn LT. Design and characterization of calcium phosphate ceramic scaffolds for bone tissue engineering. Dent Mater. 2016 Jan;32(1):43-53. https://doi.org/10.1016/i.dental.2015.09.008

37. Wolf M, Wurm A, Heinemann F, Gerber T, Reichert C, Jäger A, et al. The effect of patient age on bone formation using a fully synthetic nanocrystalline bone augmentation material in maxillary sinus grafting. Int J Oral Maxillofac Implants. 2014 Jul-Aug;29(4):976-83. https://doi.org/10.11607/jomi.3525

38. Lelli M, Putignano A, Marchetti M, Foltran I, Mangani F, Procaccini M, et al. Remineralization and repair of enamel surface by biomimetic Zn-carbonate hydroxyapatite containing toothpaste: a comparative in vivo study. Front Physiol. 2014 Sep;5:333. https://doi.org/10.3389/fphys.2014.00333

39. Nguyen NK, Leoni M, Maniglio D, Migliaresi C. Hydroxyapatite nanorods: soft-template synthesis, characterization and preliminary in vitro tests. J Biomater Appl. 2013 Jul;28(1):49-61. https://doi.org/10.1177/0885328212437065

40. Trommer RM, Santos LA, Bergmann CP. Nanostructured hydroxyapatite powders produced by a flame-based technique. Mater Sci Eng C. 2009 Aug;29(6):1770-5. https://doi.org/10.1016/i.msec.2009.02.006

41. Vecbiskena L, Gross KA, Riekstina U, Yang TC. Crystallized nano-sized alpha-tricalcium phosphate from amorphous calcium phosphate: microstructure, cementation and cell response. Biomed Mater. 2015 Apr;10(2):025009.

https://doi.org/10.1088/1748-6041/10/2/025009 